Vol. 39(1), pp. 47-58, June 2020

ISSN 1821-536X (print)

ISSN 2619-8789 (electronic)
Tanzania Journal of Engineering and Technology

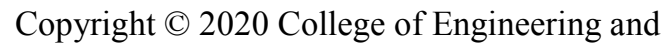

Technology, University of Dar es Salaam

Full Length Research Paper

\title{
Modeling and Control of Solar PV with Battery Energy Storage for Rural Electrification
}

\author{
Irene H. Masenge and Francis Mwasilu
}

Department of Electrical Engineering, University of Dar es Salaam, Tanzania.

E-mail: irenehenry6@gmail.com, fmwasilu@udsm.ac.tz

\begin{abstract}
In rural areas where electric power grid network is rarely available, power generation from renewable energy resource such as solar photovoltaic (PV) is mostly accomplished in standalone mode. The standalone solar PV system requires energy storage device to achieve reliable power supply to the end users. This paper presents modelling and coordination control of solar PV with battery energy storage system (BESS) for rural-electrification applications. The proposed control is accomplished via a bidirectional buck-boost converter with the objective of maintaining voltage at the DC bus constant. Simulation results based-on MATLAB/Simulink platform confirms good performance of the proposed system.
\end{abstract}

Keywords: Photovoltaic (PV), Energy Storage System (ESS), Maximum Power Point Tracking (MPPT)

\section{INTRODUCTION}

Electricity generation worldwide is mainly attained from non-renewable sources such as fossil fuel and renewable energy sources (RESs) such as solar PV. However, the rapid depletion of non-renewable sources and release of greenhouse gases to the atmosphere have escalated the global warming calamity. This has made the choice of the renewable energy sources inevitable as they are inexhaustible and have less adverse impacts on the environment (Kainkwa, 2008). Nevertheless, the RESs have disadvantages, which are their incapability to ensure reliability and their nature that depends on weather conditions (Muralikrishna and Lakshminarayana, 2008).
There is excessive demand of energy in rural Tanzania in which the main energy consumption (about $60-80 \%$ ) is biomass in the form of firewood and charcoal (Rosillo-Calle, 2016). The Tanzania's Rural Electrification Program of 20132022 has the goal of increasing electricity access to at least $75 \%$ by 2033 (Teske et al., 2017). To enhance this goal in Tanzanian rural areas, the effective extraction of energy from the RESs such as solar PV and wind, which are vastly available, is inevitable.

The use of RESs for power generation can be either in standalone or grid connected modes. Currently, the promotion of RESs in standalone operation has been largely achieved all over the world (Deshmukh and Singh, 2019). However, since these sources 
cannot deliver continuous energy, the use of energy storage system (ESS) is unavoidable so as to satisfy the power demands (Nehrir et al., 2011).

Recently, solar PV has been one of the used RES mainly for power generation due to decrease in its installation cost and mature technology (Wu et al., 2014; Dizqah et al., 2014; Quintana et al., 2013; Daniel and AmmasaiGounden, 2004; Mellit et al., 2007). Nevertheless, the nature of sun irradiation that is intermittent, has been a challenge in operation of the solar PV generator leading to an oscillatory output power. To mitigate this problem, an energy storage system (ESS) is integrated with the solar PV system (Nehrir et al., 2011; Vazquez et al., 2010). However, ESS is imperative for the efficient operation of standalone solar PV systems. The commonly employed ESS with renewable energy system is the battery ESS (BESS) (Riffonneau et al., 2011; Teleke et al., 2010). The BESS needs a proper charging control for effective operation with the varying solar insolation.

The approach that has been widely used for battery charging in solar PV system is that of direct connection of battery bank to the solar array (Yamazaki and Muramoto, 1998). The setback of this method is that the battery $100 \%$ state of charge (SOC) does not always correspond to the overcharge limit and voltage regulation set point. Another approach is that of on/off control in which there is either a full application of solar array current or no current to the battery bank (Woodworth et al., 1994). The drawback of this approach is the prolonged time to complete the charging process since during off time no charge is transferred to the battery. Charge equalization algorithms is another approach, but there is limitation in feasibility of this approach since there is a requirement to access individual cells or blocks of cells (Mishra et al., 1996). Duryea et al. (1999) proposed an algorithm based on ampere-hour measurements, but this method is affected by error in current measurement that affects determination of SOC and battery lifetime. Furthermore, to achieve longer battery life time and high SOC, Koutroulis and Kalaitzakis (2004) suggested a control strategy for battery charging.

In this paper, modeling of solar PV together with the coordination control between the solar PV and BESS is proposed. This control strategy is attained through a bidirectional buckboost converter that links between the BESS and the DC bus. The control strategy is proposed in order to maintain the voltage at the DC bus by charging and discharging the battery through a bidirectional DC-DC converter. Moreover, the use of proper Maximum Power Point Tracking (MPPT) algorithm is inevitable in order to obtain maximum possible power at any instant from the solar PV generator. Various MPPT algorithms such as perturb and observe (P\&O) and incremental conductance have been proposed in previous literature (Liu et al., 2008) (Tafticht et al., 2008). The P\&O MPPT algorithm is adopted in this work due to its simplicity. The maximum power point (MPP) is attained by using a boost converter that links the solar PV with the DC bus. The system setup is simulated in MATLAB/Simulink software in order to validate the system's performance. The software is used due to its accuracy and simplicity. 


\section{METHODS AND MATERIALS}

\section{Proposed System Configuration}

The system layout investigated in this paper is shown in Figure 1. It consists of a solar PV connected through a DC/DC boost converter where the MPPT algorithm measures the current $\left(\mathrm{I}_{\mathrm{PV}}\right)$ and voltage $\left(\mathrm{V}_{\mathrm{PV}}\right)$ values of the solar PV and outputs the duty cycle that switches the boost converter in order to extract maximum power from the solar $\mathrm{PV}$. On the other hand, the charging and discharging of the battery is performed by the battery charge controller through the bidirectional buck-boost converter, whereby the parameters considered are battery current $\left(\mathrm{I}_{\mathrm{b}}\right)$ and voltage at the $\mathrm{DC}$ bus $\left(\mathrm{V}_{\mathrm{DC}}\right)$ to ensure that the voltage at the DC bus is kept constant.

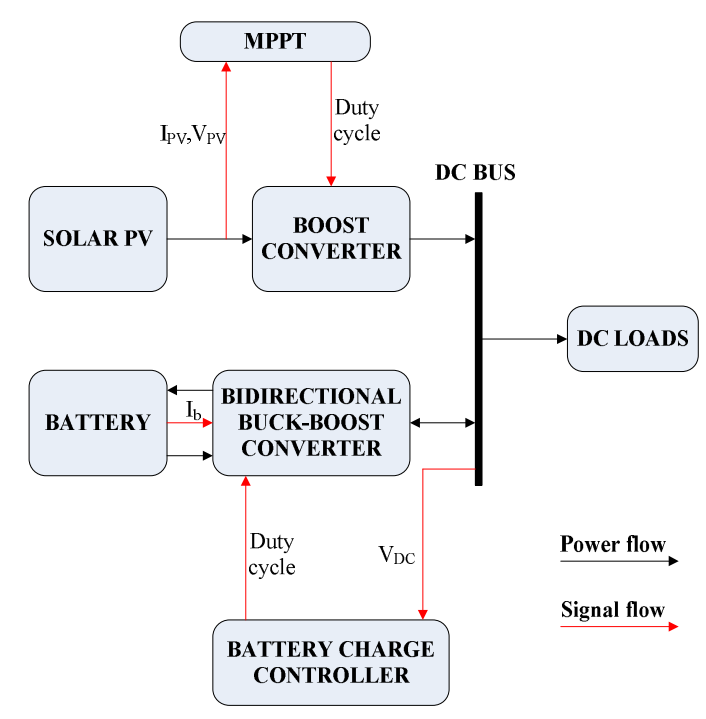

Figure 1: The proposed system layout

\section{PV System Modelling and MPPT Control}

The system is designed to operate at a DC bus voltage of $750 \mathrm{~V}$ as will be described later in this work. Moreover, considering the needs of loads in rural areas, the solar PV generates up to 200
$\mathrm{kW}$ Solar PV as the main source of power operates at Maximum Power Point (MPP) while the battery ESS complements the entire system by charging or discharging in order to balance power supplied to the DC loads.

\section{Solar PV modelling}

In the literature, various equivalent circuits of PV cell have been proposed, but the most commonly used model is the single-diode circuit due to its simplicity and accuracy (Yazdani et al., 2010; Ye et al., 2012). The single diode equivalent circuit of the PV cell is shown in Figure 2. The circuit is comprised of a diode in parallel with a current source, a series and parallel resistance. The basic equation is as shown in equation (1).

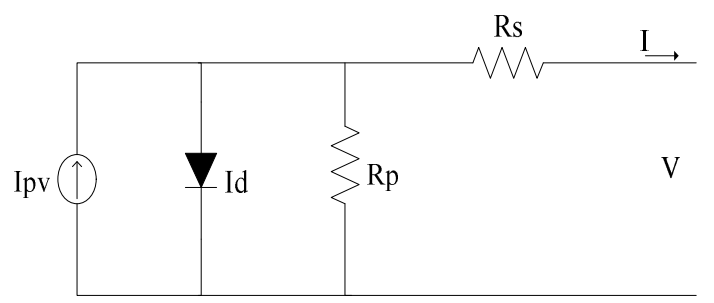

Figure 2: $P V$ cell single diode equivalent circuit

$$
\begin{array}{r}
I=I_{p v}-I_{0}\left[\exp \left(\frac{V+I R_{s}}{V_{t} a}\right)-1\right] \\
-\frac{V+I R_{s}}{R_{p}} \ldots \ldots \ldots \ldots
\end{array}
$$

where $I_{p v}$ and $I_{o}$ are the PV and saturation currents of the array, respectively. $R_{S}$ is the equivalent series resistance of the array and $R_{p}$ is the equivalent parallel resistance; $a$ is the diode ideality constant, $\mathrm{V}_{\mathrm{t}}$ is the thermal array voltage which is obtained by using equation (2).

$V_{t}=\frac{N_{s} k T}{q}$

where $\mathrm{N}_{\mathrm{S}}$ is the number of series connected cells, $\mathrm{k}$ is the Boltzmann constant $\left(1.3806503 \times 10^{-23} \mathrm{~J} / \mathrm{K}\right), T$ is 
the $p-n$ junction temperature (in Kelvin), $q$ is the charge of the electron $\left(1.60217646 \times 10^{-19} \mathrm{C}\right)$.

The module of solar PV array is designed using MATLAB software based on the system requirements. The considered solar PV generator is capable of generating up to $200 \mathrm{~kW}$. The voltage required for maximum power is $54.7 \mathrm{~V}$ for a single module. Then by connecting 10 solar PV modules in series $\left(\mathrm{N}_{\mathrm{S}}\right)$ the voltage $\left(\mathrm{V}_{\mathrm{mPV}}\right)$, is obtained as depicted in equation (3).

$$
V_{m P V}=V_{m p} \times N_{s}
$$

Then, the system current value is determined by equation (4).

$$
I_{m P V}=\frac{P}{V}
$$

Table 1 shows the parameters of the PV array module.

The current required for the available maximum power is $5.58 \mathrm{~A}$ for a single module as shown in Table 1 . Then, the number of parallel connected strings of the solar PV modules $\left(\mathrm{N}_{\mathrm{P}}\right)$ is obtained as shown in equation (5).

$N_{p}=\frac{I}{I_{m p}}$

The light-produced current of the PV cell is influenced by the solar irradiance and temperature (Sera et al., 2007; Driesse et al., 2007; De Soto et al., 2006; Kou et al., 1998). The simulation of one module was carried out for different irradiance and temperature levels to demonstrate this variation. The variation of irradiance level was from $250 \mathrm{~W} / \mathrm{m}^{2}$ to $1000 \mathrm{~W} / \mathrm{m}^{2}$ and the resultant $P-V$ curve is as shown in Figure 3. It is observed that as the irradiance increases, the power from the solar PV also increases. On the other hand, the variations of temperature is set from $2^{\circ} \mathrm{C}$ to $7^{\circ} \mathrm{C}$ and the resulting $P$ $V$ curve is as shown in Figure 4. It was observed that the solar PV power decreases with the increase in temperature. This concludes the necessity of tracking the maximum power point (MPP) at any instant on the solar PV for effective generation of power as this MPP varies with irradiance and temperature.

Table 1: Solar Module Properties

\begin{tabular}{|l|c|}
\hline $\begin{array}{l}\text { Module data (Sun } \\
\text { Power SPR-305E- } \\
\text { WHT-D) }\end{array}$ & Values \\
\hline $\begin{array}{l}\text { Maximum power, } \\
\text { Pm at }\end{array}$ & $305.226 \mathrm{~W}$ \\
\hline $\begin{array}{l}\text { Voltage power } \\
\text { maximum at } \\
\text { point, } \mathrm{V}_{\mathrm{mp}}\end{array}$ & $54.7 \mathrm{~V}$ \\
\hline $\begin{array}{l}\text { Current } \\
\text { maximum power } \\
\text { point, } \mathrm{I}_{\mathrm{mp}}\end{array}$ & $5.58 \mathrm{~A}$ \\
\hline $\begin{array}{l}\text { Cells per module, } \\
\mathrm{N}_{\text {cell }}\end{array}$ & 96 \\
\hline $\begin{array}{l}\text { Open circuit } \\
\text { voltage, } \mathrm{V}_{\mathrm{OC}} \text { circuit }\end{array}$ & $64.2 \mathrm{~V}$ \\
\hline $\begin{array}{l}\text { Short } \\
\text { current, } \mathrm{I}_{\mathrm{SC}}\end{array}$ & $-0.27269 \% /{ }^{\circ} \mathrm{C}$ \\
\hline $\begin{array}{l}\text { Voltage/temp. } \\
\text { coefficient, } \mathrm{K}_{\mathrm{V}}\end{array}$ & $0.061745 \% /{ }^{\circ} \mathrm{C}$ \\
\hline $\begin{array}{l}\text { Current/temp. } \\
\text { coefficient, } \mathrm{K}_{\mathrm{i}}\end{array}$ & \\
\hline
\end{tabular}

A DC/DC boost converter which connects the solar PV to the DC bus is controlled via an MPPT algorithm. The dynamics of irradiance and temperature necessitates the need of an MPPT algorithm that continuously updates the duty cycle to enhance the tracking speed and accuracy (Abdulkadir et al., 2012). Figure 5 shows the solar PV connected through the boost converter to the DC bus. 


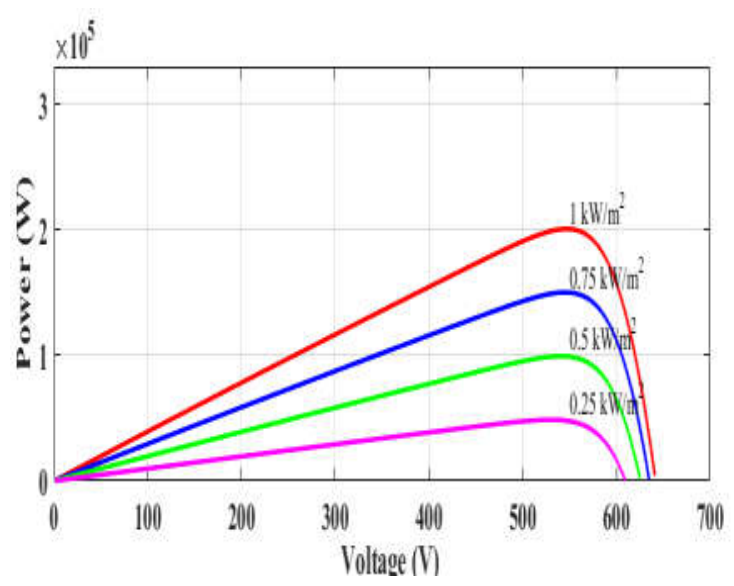

Figure 3: P-V Curve at Various Irradiances

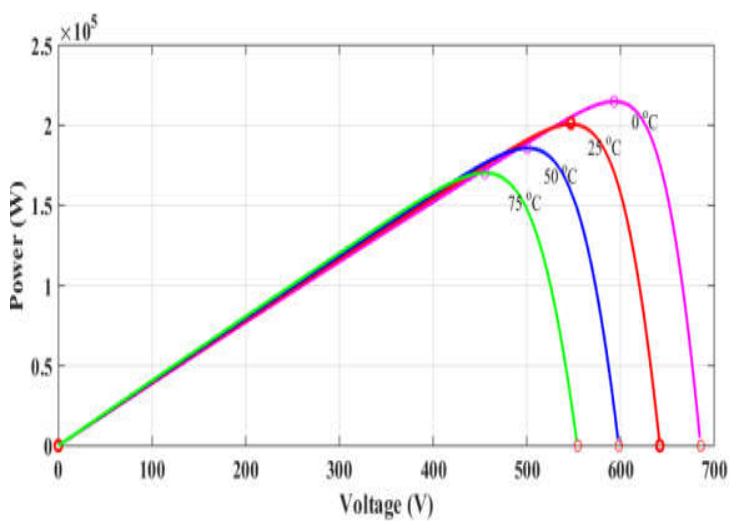

Figure 4: P-V Curve at Various Temperature

\section{Solar PV and MPPT algorithm design}

For the extraction of maximum power, the solar PV current $\left(I_{p}\right)$ and voltage $\left(V_{p}\right)$ are sensed and the MPPT controller adjusts the duty cycle so that the MPP is precisely tracked. Tracking of the MPP can be carried out using various techniques. The Perturb and Observe (P\&O), which involves injection of small perturbation to the system resulting to driving of the operating point towards the MPP is adopted due to its simplicity (Ayang et al., 2018).

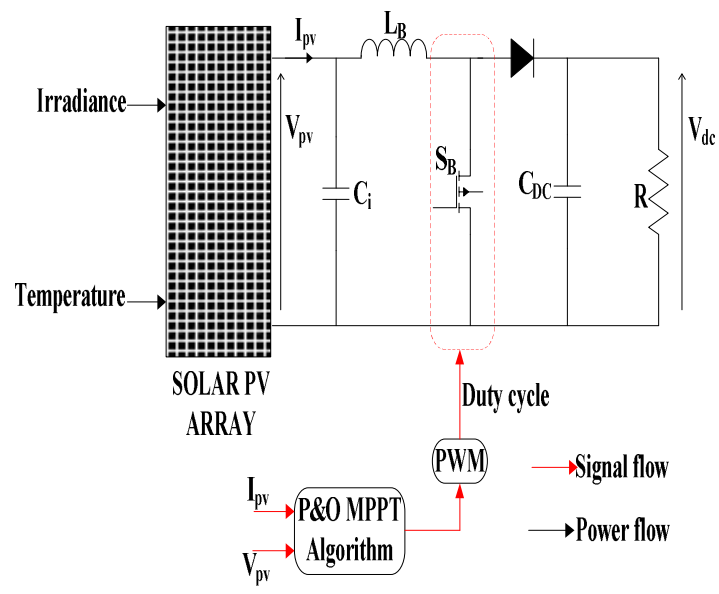

Figure 5: Solar PV with boost converter

In the MPPT algorithm, the instantaneous values of voltage, $V(t)$ and current, $I(t)$ are measured, then power, $P(t)$ is calculated. The deviation in voltage $(\Delta \mathrm{V})$ and power $(\Delta \mathrm{P})$ are obtained, compared and appropriate action is taken on the reference voltage value $\left(\mathrm{V}_{\text {ref }}\right)$ in order to track the MPP accordingly. Figure 6 shows the flow chart of the MPPT algorithm implemented.

\section{Converters Design, Battery ESS Sizing and System Control}

\section{Boost converter design}

The input voltage of a boost converter is the voltage of the PV array $\left(V_{P C}\right)$ at MPP, which is calculated using equation (3). For the power transfer, the minimum DC bus voltage $\left(V_{d c}\right)$ is to be at least equal to 1.1 times the peak of line voltage $\left(V_{l}\right)$ as shown in equation (6) (Kewat et al., 2017).

$$
V_{d c}=1.1 \times \sqrt{2} \times V_{l}
$$




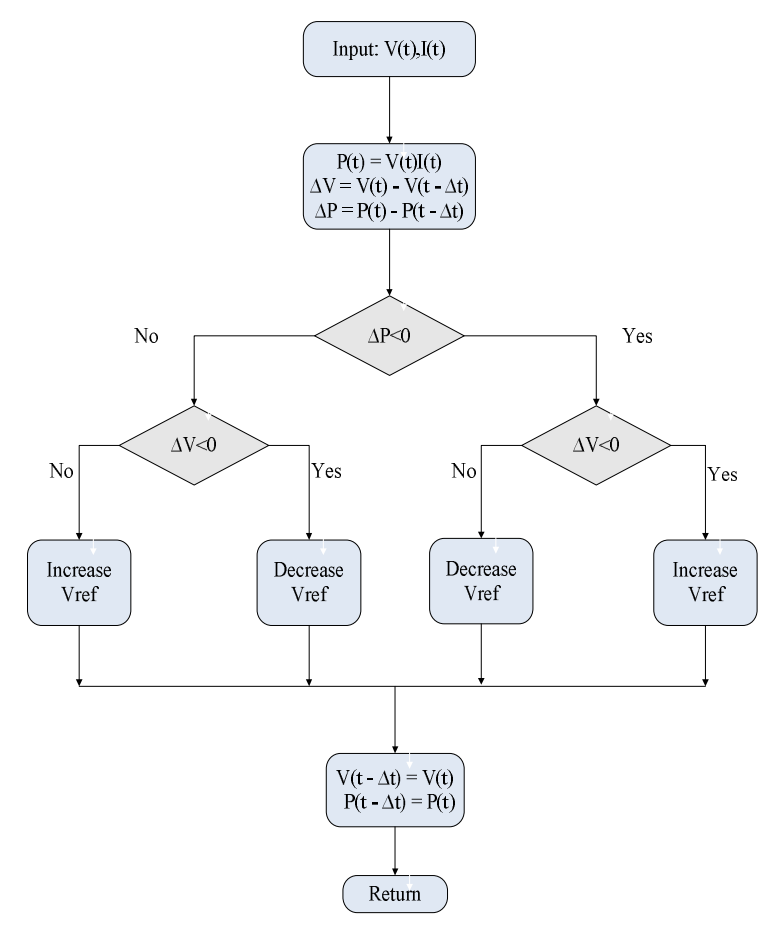

Figure 6: The flowchart of P\&O algorithm

The designed value of the boost inductor $\left(\mathrm{L}_{\mathrm{B}}\right)$ is given by equation (7) (Philip et al., 2016).

$L_{B}=\frac{V_{m p} \times D}{\Delta i_{r p} \times f_{s}}$

where $V_{m p}$ is the voltage at MPP, $D$ is the duty cycle, $\Delta i_{r p}$ is the ripple current, considered as $10 \%$ of the MPP solar PV current and $f_{s}$ is the switching frequency.

The input capacitor is calculated using equation (8) (Rashid, 2009).

$C_{i} \geq \frac{D}{8 \times f_{S} \times L_{B} \times \Delta V}$

where $\Delta V$ is input voltage ripple of $1 \%$.

Also, the DC bus capacitor considering a voltage ripple $\left(\Delta V_{d c}\right)$ of $1.5 \%$ is calculated as shown in equation (9).

$C_{D C}=\frac{P_{d c}}{2 \times \omega \times V_{d c} \times \Delta V_{d c}}$
Where $P_{d c}$ is DC bus power, $\mathrm{V}_{\mathrm{dc}}$ is DC bus voltage and $\omega$ is the angular frequency.

\section{Battery ESS sizing}

The proposed solar-PV system is designed to provide load requirement $\left(P_{\text {req }}\right)$ of $200 \mathrm{~kW}$ for time $\left(t_{h r s}\right)$ up to 24 hrs. In sizing the battery an additional $20 \%$ of the load requirement is considered to account for the energy that is lost in the course of energy exchange. Considering the battery voltage $\left(\mathrm{V}_{\mathrm{b}}\right)$ of $240 \mathrm{~V}$ that corresponds to the desired DC bus voltage, the Ampere-Hour rating of the battery $\left(Q_{r}\right)$ is obtained as shown in equation (10) (Tiwari et al., 2018).

Battery Rating $\left(Q_{r}\right)$

$=\frac{P_{r e q} \times t_{h r s}+0.2\left(P_{r e q} \times t_{h r s}\right)}{V_{b}}$

\section{Bidirectional Buck-Boost converter design}

The bidirectional buck-boost converter connects the battery ESS to the DC bus. This converter is designed to function as the buck converter while charging the battery and as boost converter on discharging mode. The proposed circuit showing solar PV and battery connected via bidirectional buck-boost converter is as shown in Figure 7.

On charging the battery, the filter inductor $\left(L_{B B}\right)$ of the battery is designed as presented in equation (11) (Kewat et al., 2017).

$D=V_{b} / V_{d c}$

$L_{B B}=\frac{D\left(V_{d c}-V_{b}\right)}{f_{S} \Delta I_{L}}$

where $V_{d c}$ is DC bus voltage, $V_{b}$ is battery voltage, $D$ is the duty cycle, $f_{s}$ is the switching frequency, $\Delta I_{L}$ is the 
current ripple and is taken as $20 \%$ of the charging current.

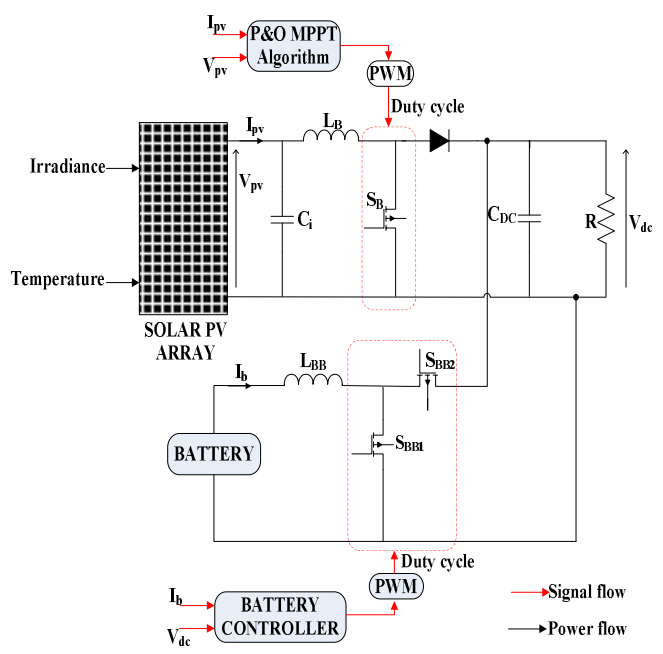

Figure 7: Solar PV with battery via bidirectional buck-boost converter

On discharging the battery, the filter inductor of the battery is designed as depicted in expression (12).

$D=\frac{\left(V_{d c}-V_{b}\right)}{V_{d c}}$

$L_{B B}=\frac{D V_{b}}{f_{S} \Delta I_{L}} \ldots \ldots \ldots \ldots \ldots \ldots \ldots \ldots \ldots \ldots \ldots \ldots$

Here, $V_{d c}$ is DC bus voltage, $V_{b}$ is battery voltage, $D$ is the duty cycle, $f_{S}$ is the switching frequency, $\Delta I_{L}$ is the current ripple and is considered to be $20 \%$ of the discharging current.

\section{Battery control through a bidirectional Buck-Boost converter}

The main objective of this control is to maintain DC bus voltage constant. The bidirectional buck boost converter maintains the DC bus voltage so as to ensure that there is continuous flow of power between the DC bus and the battery ESS (Jayalakshmi et al., 2014). Hence, the converter is controlled in a manner that the DC bus voltage remains constant during the changes in solar variables and load variations. Figure 8 shows the control strategy for the bidirectional buck-boost converter.

The voltage $V_{d c}$ is compared with reference voltage $V_{\text {ref }}$ to get the error signal that is passed through the first PI controller to produce the reference battery current, $I_{b r e f}$. Then, this reference current is compared with the sensed battery current, $I_{b}$ to obtain an error signal that is passed through the second PI controller to obtain the control signal. The control signal is then compared with a carrier signal to obtain switching pulses. When the DC bus voltage $V_{d c}$ is greater than the reference voltage $V_{r e f}$ and the state of charge (SOC) is within the accepted range ( $20 \%$ to $80 \%$ ), switch $S_{B B 2}$ is activated to run the circuit as a buck converter and when $V_{d c}$ is less than $V_{r e f}$ and SOC is between $20 \%$ and $80 \%$ switch $S_{B B 1}$ is activated to run the circuit as a boost converter. The PI controllers are tuned based on the tuning method described in Visioli (2006). The control parameters that results to a constant DC bus voltage are listed in Table 2.

Table 2: Controller Parameters

\begin{tabular}{|l|c|c|}
\hline Gain & $\mathbf{K}_{\mathbf{p}}$ & $\mathbf{K}_{\mathbf{i}}$ \\
\hline Voltage loop & 0.001 & 45 \\
\hline Current loop & 0.001 & 0.00035 \\
\hline
\end{tabular}




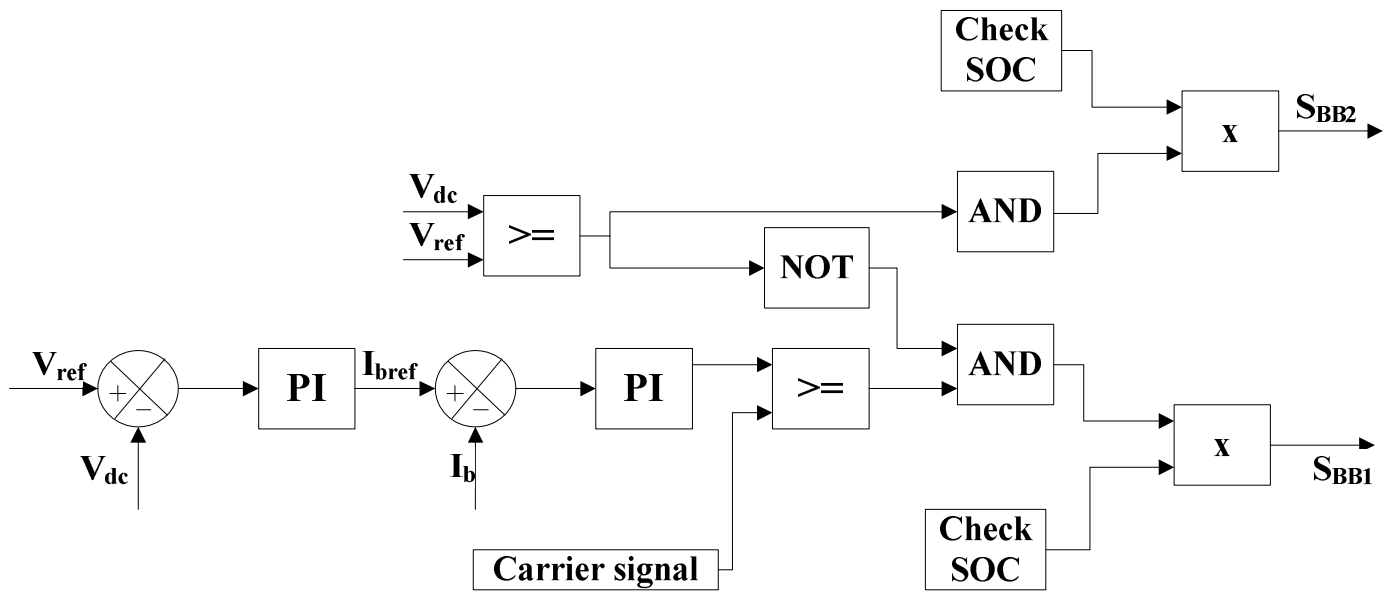

Figure 8: Control strategy for bidirectional buck boost converter

\section{RESULTS AND DISCUSSION}

In this section, simulation results of the solar PV system are presented to verify the effectiveness and feasibility of the proposed strategies. The simulations are carried out in MATLAB/Simulink platform since it is accurate and simple to use. The parameters used in this simulation studies are shown in Table 3.

Case 1: The solar PV is first tested without connection of the battery ESS. Variation of irradiance and temperature is made as shown in Figure 9 whereby initially temperature is maintained constant at $25^{\circ} \mathrm{C}$ for $6 \mathrm{~s}$. Then, during this time, irradiance is varied whereby from $0 \mathrm{~s}$ to $1 \mathrm{~s}$ irradiance is at $1000 \mathrm{~W} / \mathrm{m}^{2}$ and the DC bus voltage is observed to increase as shown in Figure 10 to the desired voltage of $750 \mathrm{~V}$. The irradiance is then decreased to 750 $\mathrm{W} / \mathrm{m}^{2}$ from $1 \mathrm{~s}$ to $4 \mathrm{~s}$ that led to the decrease of the DC bus voltage to $620 \mathrm{~V}$. Irradiance is then increased to $1000 \mathrm{~W} / \mathrm{m}^{2}$ from $4 \mathrm{~s}$ to $6 \mathrm{~s}$ and it is observed that the DC bus voltage increased simultaneously and then maintained at $750 \mathrm{~V}$. Afterwards, irradiance is maintained at 1000 $\mathrm{W} / \mathrm{m}^{2}$ up to $12 \mathrm{~s}$ and the temperature is decreased from $25^{\circ} \mathrm{C}$ to $10^{\circ} \mathrm{C}$ from $6 \mathrm{~s}$ to $7.5 \mathrm{~s}$. It was observed that the DC bus voltage increased to $780 \mathrm{~V}$. After that the temperature is increased to $30^{\circ} \mathrm{C}$ from $7.5 \mathrm{~s}$ to $12 \mathrm{~s}$, and the DC bus voltage decreased from $780 \mathrm{~V}$ to 745 V. Hence, it can be observed that the DC bus voltage varies depending on the irradiance and temperature values.
Case 2: On connection of the battery via a bidirectional buck-boost converter, variation of irradiance and temperature is made as shown in Figure 9. It is observed that the DC bus voltage just started to decrease and the controller at the battery ESS is being discharged as observed in Figures 11 and 12, respectively, to maintain the desired DC bus voltage. From $4.5 \mathrm{~s}$ to $12 \mathrm{~s}$ in Figure 9 the irradiance is maintained at 1000 $\mathrm{W} / \mathrm{m}^{2}$ and temperature is decreased from $25^{\circ} \mathrm{C}$ to $10^{\circ} \mathrm{C}$ at $6 \mathrm{~s}$ to $7.5 \mathrm{~s}$, the controller also responded accordingly, whereby the battery is charged as shown in Figure 12 to maintain the $\mathrm{DC}$ bus voltage. Also, when the temperature was increased from $10^{\circ} \mathrm{C}$ to $30^{\circ} \mathrm{C}$ at $7.5 \mathrm{~s}$ to 12 $\mathrm{s}$ the controller maintained the desired DC bus voltage by discharging the battery as depicted in Figure 12.
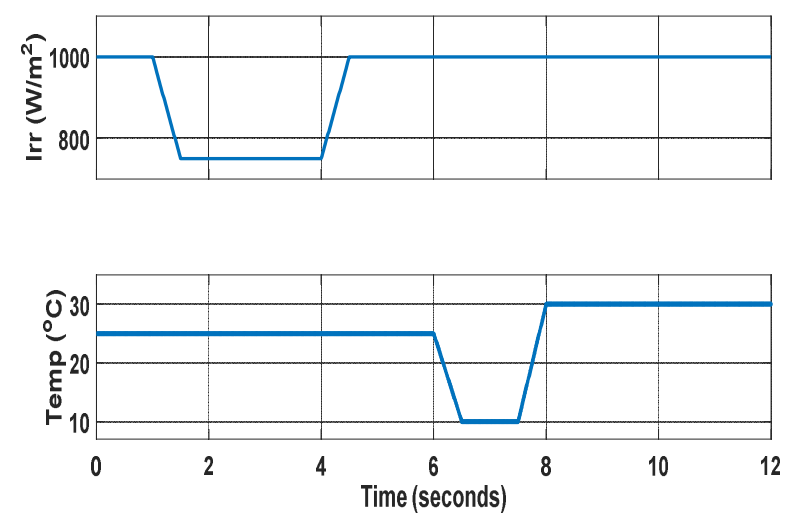

Figure 9: Varying irradiance and temperature input values to the PV array 
Table 4: Simulation Parameters

\begin{tabular}{|l|l|}
\hline DC bus voltage: $V_{d c}$ & $750 \mathrm{~V}$ \\
\hline $\begin{array}{l}\text { Number of parallel PV } \\
\text { modules: } N_{p}\end{array}$ & 66 \\
\hline $\begin{array}{l}\text { Number of series PV } \\
\text { modules: } N_{S}\end{array}$ & 10 \\
\hline $\begin{array}{l}\text { PV voltage at maximum } \\
\text { power point: } V_{m P V}\end{array}$ & $547 \mathrm{~V}$ \\
\hline $\begin{array}{l}\text { PV current at maximum } \\
\text { power point: } I_{m P V}\end{array}$ & $365.63 \mathrm{~A}$ \\
\hline Boost Converter Parameters \\
\hline Inductor: $L_{B}$ & $200.5 \mu \mathrm{H}$ \\
\hline Capacitor: $C_{i}$ & $1538.66 \mu F$ \\
\hline Capacitor: $C_{D C}$ & $37725.6 \mu F$ \\
\hline Bidirectional Buck-Boost Parameters \\
\hline Inductor: $L_{B B}$ & $14.87 \mu \mathrm{H}$ \\
\hline Lead-acid Battery Parameters \\
\hline Rated Voltage & $240 \mathrm{~V}$ \\
\hline Rated Capacity & $24000 \mathrm{Ah}$ \\
\hline Nominal Discharge Current & $4800 \mathrm{~A}$ \\
\hline Internal Resistance & $0.0001 \Omega$ \\
\hline Cut-off Voltage & $180 \mathrm{~V}$ \\
\hline $\begin{array}{l}\text { Exponential zone [Voltage, } \\
\text { Capacity] }\end{array}$ & {$\left[\begin{array}{c}244.3421 \mathrm{~V} \\
80 \mathrm{Ah}\end{array}\right.$} \\
\hline
\end{tabular}

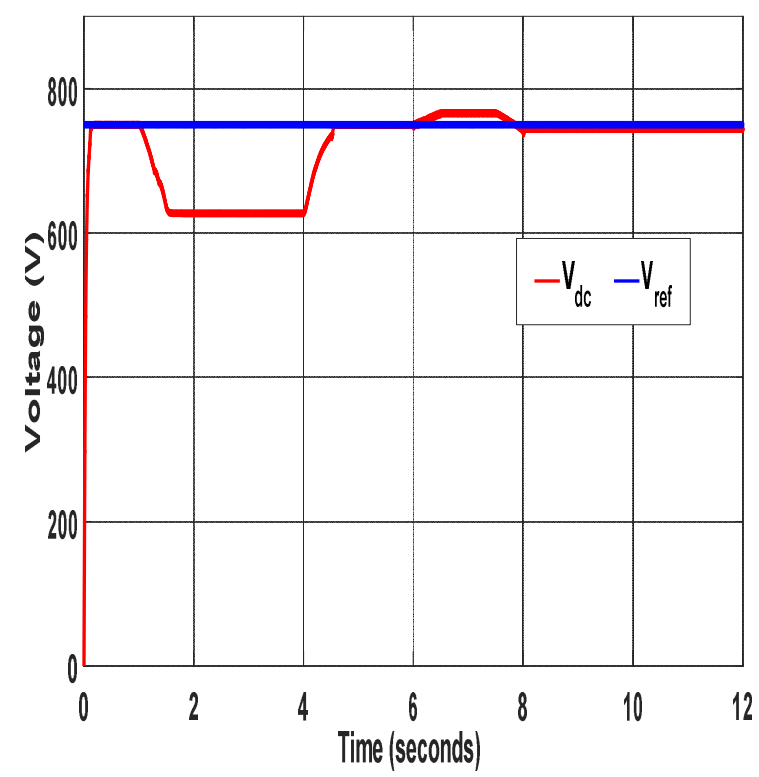

Figure 10: Voltages on varying irradiance and temperature

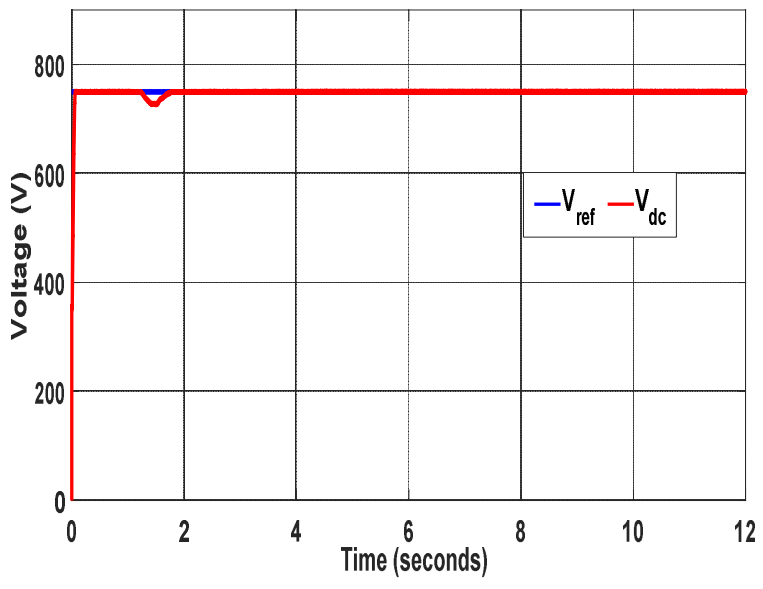

Figure 11: Voltages on varying irradiance and temperature

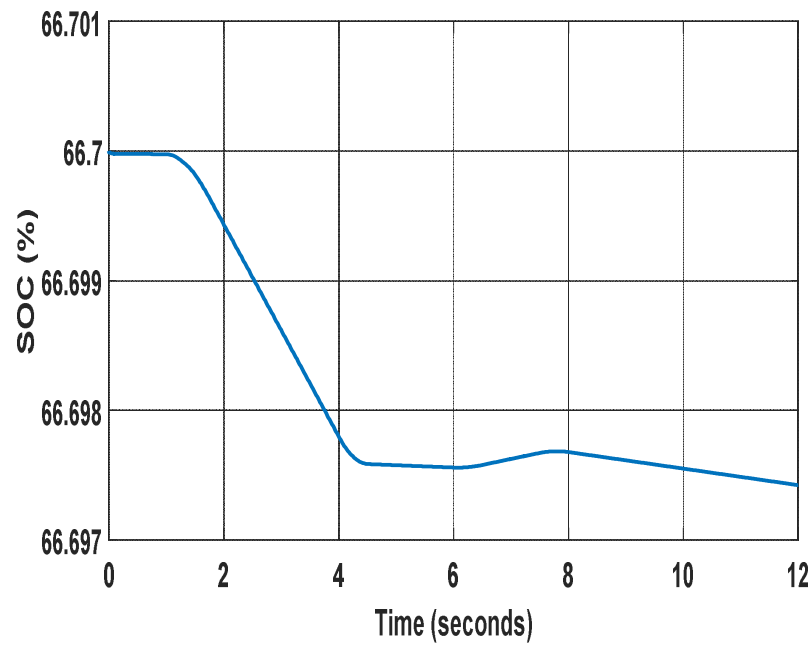

Figure 12: Battery SOC on varying irradiance and temperature

Case 3: The controller is also tested with varying load under standard temperature of $25^{\circ} \mathrm{C}$ and irradiance of $750 \mathrm{~W} / \mathrm{m}^{2}$. At starting, the first load is connected at time $0 \mathrm{~s}$ and the DC bus voltage increased up to the desired DC bus voltage and is maintained as illustrated in Figure 13 whereby the battery is being charged as seen in Figure 15. At $2 \mathrm{~s}$ the second load is added whereby the DC bus current increased from $110 \mathrm{~A}$ to $270 \mathrm{~A}$. Also, the DC bus voltage dropped to $715 \mathrm{~V}$ at $2.03 \mathrm{~s}$ as shown in Figure 14 and Figure 13, respectively, the controller operated by discharging the battery as shown in Figure 15 and the desired DC bus voltage was obtained at $2.4 \mathrm{~s}$ as observed in Figure 13. At 4 $\mathrm{s}$ the third load is added that led to the drop in DC bus voltage to $683.6 \mathrm{~V}$ and rise in DC bus 
current from $270 \mathrm{~A}$ to $400 \mathrm{~A}$ as shown in Figure 14, respectively. The controller operated by discharging the battery as shown in Figure 15 in order to obtain the DC bus voltage at 750 $\mathrm{V}$ as depicted in Figure 13. Observing the three cases, the proposed system demonstrates a good performance in maintaining the voltage at the DC bus constant at $750 \mathrm{~V}$.

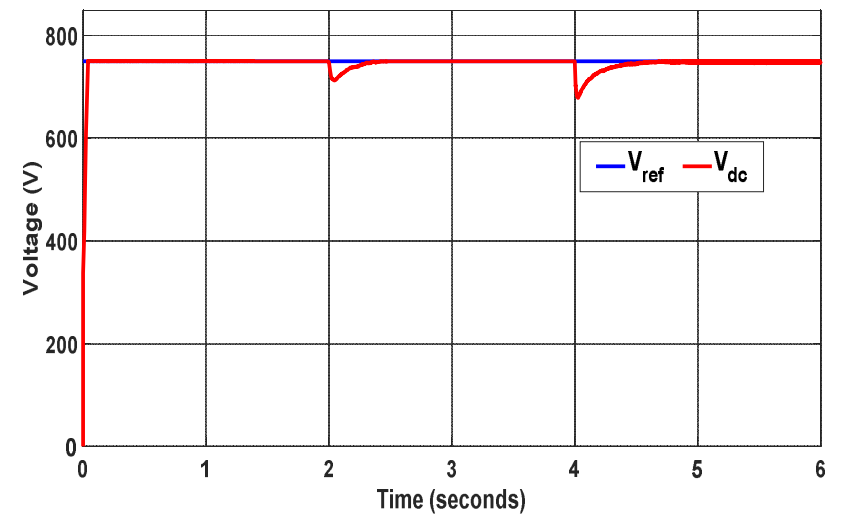

Figure 13: DC bus voltage on step load change

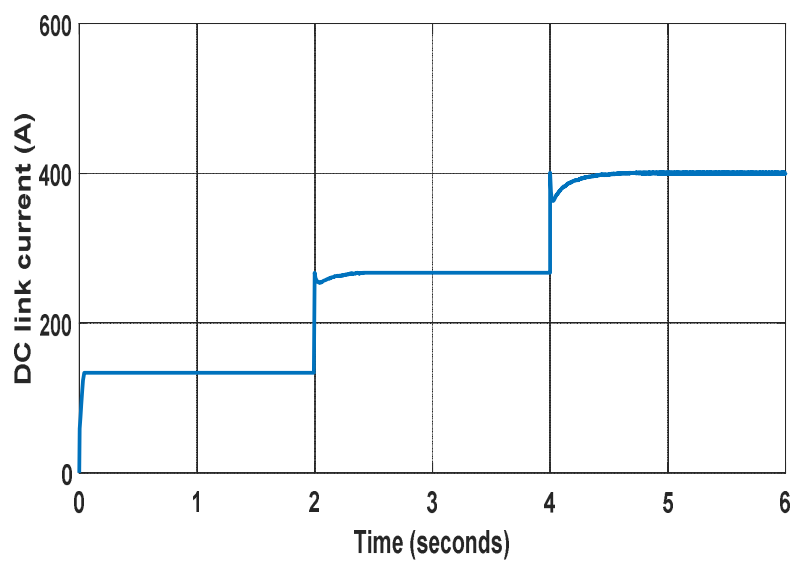

Figure 14: DC bus current on step load change

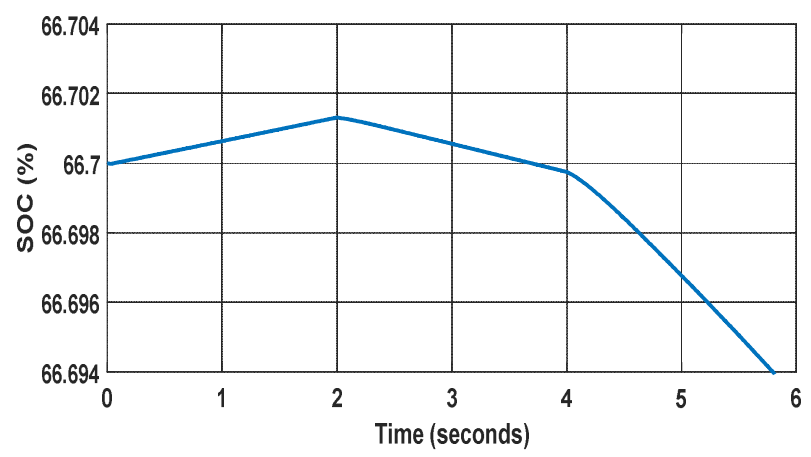

Figure 15: Battery SOC on step load changes

\section{CONCLUSIONS}

In this paper, modelling and coordination control of solar PV with battery energy storage system for rural electrification applications has been presented. The proposed control scheme has been accomplished through a bidirectional buck-boost converter maintaining the DC bus voltage constant at $750 \mathrm{~V}$. This voltage at the DC bus was maintained constant regardless of the change in solar PV input parameters and load variations. Performance of the system has been validated through simulations carried out in MATLAB/Simulink platform where different scenarios were successfully tested and demonstrated excellent results. However, incorporating this system with other renewable energy sources would improve the system's reliability and reduce the entire system's cost for rural electrification.

\section{REFERENCES}

Abdulkadir M., Samosir A.S. and Yatim A.H.M. (2012). Modelling and simulation of maximum power point tracking of photovoltaic system in Simulink model. In December 2012 IEEE International Conference on Power and Energy (PECon), 325-330.

DOI:

\subsection{9/PECon.2012.6450231}

Ayang A., Saad M., Ouhrouche M. and Wamkeue R. (2018). Modeling, P\&O MPPT and PI controls and performance analysis of $\mathrm{PV} /$ Energy storage hybrid power system. In November 2018 4th International Conference on Renewable Energies for Developing Countries (REDEC), 1-6. DOI: 10.1109/REDEC.2018.8597744

Daniel S.A. and AmmasaiGounden N. (2004). A novel hybrid isolated generating system based on PV fed inverter-assisted winddriven induction generators. IEEE Transactions on energy conversion, 19(2): 416-422. DOI: $10.1109 /$ TEC. 2004.827031

De Soto W., Klein S.A. and Beckman W.A. (2006). Improvement and validation of a model for photovoltaic array performance. Solar Energy, 80(1): 78-88. DOI: $\underline{10.1016 / \text { j.solener.2005.06.010 }}$ 
Deshmukh M.K. and Singh A.B. (2019). Online monitoring of roof-mounted standalone solar photovoltaic system on residential building. Materials Today: Proceedings. DOI: 10.1016/j.matpr.2019.06.487

Dizqah A.M., Maheri A., Busawon K., and Kamjoo A. (2014). A multivariable optimal energy management strategy for stand-alone dc microgrids. IEEE transactions on power systems, 30(5): 2278-2287. DOI: $10.1109 /$ TPWRS.2014.2360434

Driesse A., Harrison S. and Jain P. (2007). Evaluating the effectiveness of maximum power point tracking methods in photovoltaic power systems using array performance models. In June 2007 IEEE Power Electronics Specialists Conference, 145-151.

Duryea S., Islam S. and Lawrance W. (1999). A battery management system for standalone photovoltaic energy systems. In Conference Record of the October 1999 IEEE Industry Applications Conference. Thirty-Forth IAS Annual Meeting (Cat. No. 99CH36370), 4: 2649-2654. DOI:10.1109/IAS.1999.799211

Jayalakshmi N.S., Gaonkar D.N., Balan A., Patil P. and Raza S.A. (2014). Dynamic modelling and performance study of a standalone photovoltaic system with battery supplying dynamic load. International Journal of Renewable Energy Research (IJRER), 4(3): 635-640.

Kainkwa R.M.R. (2008). Survey of wind power potential for wind-based electricity at Makambako, Iringa Tanzania. Tanzania Journal of Science, 34(1): 1-9, DOI: $10.4314 /$ tjs.v34i1.44282

Kewat S., Singh B. and Hussain I. (2017). Power management in PV-battery-hydro based standalone microgrid. IET Renewable Power Generation, 12(4): 391-398. DOI: $10.1049 /$ iet-rpg.2017.0566

Kou Q., Klein S.A. and Beckman W. A. (1998). A method for estimating the longterm performance of direct-coupled PV pumping systems. Solar Energy, 64(1-3): 33-40. https://doi.org/10.1016/S0038$\underline{092 X(98) 00049-8}$
Koutroulis E. and Kalaitzakis K. (2004). Novel battery charging regulation system for photovoltaic applications. IEE ProceedingsElectric Power Applications, 151(2): 191197. DOI: $10.1049 / \mathrm{ip}$-epa:20040219

Liu F., Duan S., Liu F., Liu B. and Kang Y. (2008). A variable step size INC MPPT method for PV systems. IEEE Transactions on industrial electronics, 55(7): 2622-2628. DOI: 10.1109/TIE.2008.920550

Mellit A., Benghanem M. and Kalogirou S.A. (2007). Modeling and simulation of a standalone photovoltaic system using an adaptive artificial neural network: Proposition for a new sizing procedure. Renewable Energy, 32(2): 285-313. DOI: 10.1016/j.renene.2006.01.002

Mishra P.R., Pandey A.K. and Joshi J.C. (1996). Design of a battery voltage regulator based on maximum power point tracking and charge equalisation concepts. Solar energy materials and solar cells, 44(1): 1124 . $\quad$ https://doi.org/10.1016/0927$\underline{0248(96) 00002-5}$

Muralikrishna M. and Lakshminarayana V. (2008). Hybrid (Solar and Wind) Energy Systems for Rural Electrification. ARPN Journal of Engineering and Applied Sciences, 3(5): 50-58. Corpus ID: 16998108

Nehrir M.H., Wang C., Strunz K., Aki H., Ramakumar R., Bing J., Miao Z. and Salameh, Z. (2011). A review of hybrid renewable/alternative energy systems for electric power generation: Configurations, control, and applications. IEEE Transactions on Sustainable Energy, 2(4): 392-403. DOI: 10.1109/TSTE.2011.2157540

Philip J., Jain C., Kant K., Singh B., Mishra S., Chandra A. and Al-Haddad K. (2016). Control and implementation of a standalone solar photovoltaic hybrid system. IEEE Transactions on Industry Applications, 52(4): $\quad 3472-3479 . \quad$ DOI: 10.1109/TIA.2016.2553639

Quintana P.J., Garcia J., Guerrero J.M., Dragicevic T. and Vasquez J.C. (2013). Control of single-phase islanded PV/battery streetlight cluster based on power-line signaling. In December 2013 IEEE International Conference on New Concepts 
in Smart Cities: Fostering Public and Private Alliances (SmartMILE), 1-6, IEEE Press. https://doi.org/10.1109/SmartMILE.2013.67 08213

Rashid M.H. (2009). Power electronics: circuits, devices and applications, Pearson/Prentice Hall, ISBN 0131228153, 9780131228153

Riffonneau Y., Bacha S., Barruel F. and Ploix S. (2011). Optimal power flow management for grid connected PV systems with batteries. IEEE Transactions on sustainable Energy, 2(3): 309-320.

DOI: $10.1109 /$ TSTE.2011.2114901

Rosillo-Calle F. (2016). A review of biomass energy-shortcomings and concerns. Journal of Chemical Technology \& Biotechnology, 91(7): $\quad$ 1933-1945. https://doi.org/10.1002/jctb.4918

Sera D., Teodorescu R. and Rodriguez P. (2007). PV panel model based on datasheet values. IEEE Int. Symp. Ind. Electron. (ISIE), 2392-2396. Electrical Engineering/Electronics, Computer, Communications and Information Technology Association. https://doi.org/10.1109/ISIE.2007.4374981

Tafticht T., Agbossou K., Doumbia M.L. and Cheriti A. (2008). An improved maximum power point tracking method for photovoltaic systems. Renewable Energy, 33(7): $\quad 1508-1516 . \quad$ DOI: 10.1016/j.renene.2007.08.015

Teske S., Morris T. and Nagrath K. (2017). $100 \%$ Renewable Energy for TanzaniaAccess to renewable and affordable energy for all within one generation. Institute for Sustainable Future, University of Technology Sydney, Australia.

Teleke S., Baran M.E., Bhattacharya S. and Huang A.Q. (2010). Rule-based control of battery energy storage for dispatching intermittent renewable sources. IEEE Transactions on Sustainable Energy, 1(3): 117-124. DOI: 10.1109/TSTE.2010.2061880

Tiwari S. K., Singh B. and Goel P.K. (2018). Design and Control of Microgrid Fed by
Renewable Energy Generating Sources. IEEE Transactions on Industry Applications, 54(3): 2041-2050. DOI: $\underline{10.1109 / T I A .2018 .2793213}$

Vazquez S., Lukic S.M., Galvan E., Franquelo L.G. and Carrasco J.M. (2010). Energy storage systems for transport and grid applications. IEEE Transactions on Industrial Electronics, 57(12): 3881-3895. DOI: $10.1109 /$ TIE.2010.2076414

Woodworth J.R., Thomas M.G., Stevens J.W., Harrington S.R., Dunlop J.P. and Swamy M.R. (1994). Evaluation of the batteries and charge controllers in small stand-alone photovoltaic systems. In Proceedings of December 1994 IEEE 1st World Conference on Photovoltaic Energy ConversionWCPEC (A Joint Conference of PVSC, PVSEC and PSEC), 1: 933-945. DOI:10.1109/WCPEC.1994.520115

Wu D., Tang F., Dragicevic T., Vasquez J.C. and Guerrero J.M. (2014). Autonomous active power control for islanded ac microgrids with photovoltaic generation and energy storage system. IEEE Transactions on energy conversion, 29(4), 882-892. https://doi.org/10.1109/TEC.2014.2358612

Yamazaki T. and Muramoto K.I. (1998). An advanced solar charging and battery discharge controller unit. Renewable Energy, 15(1-4): $\quad 606-609 . \quad$ DOI: 10.1016/S0960-1481(98)00235-3

Yazdani A., Di Fazio A.R., Ghoddami H., Russo M., Kazerani M., Jatskevich J., Strunz K., Leva S. and Martinez J.A. (2010). Modeling guidelines and a benchmark for power system simulation studies of three-phase single-stage photovoltaic systems. IEEE transactions on power delivery, 26(2): 1247-1264. DOI: $10.1109 /$ TPWRD.2010.2084599

Ye L., Sun H.B., Song X.R. and Li L.C. (2012). Dynamic modeling of a hybrid wind/solar/hydro microgrid in EMTP/ATP. Renewable Energy, 39(1): 96-106. DOI: 10.1016/j.renene.2011.07.018 